\title{
The Influence of Personal Values on Organization Commitment among Foreign Workers in Malaysia's Construction Industry
}

\author{
N. L. Jamaludin, Azhar, Salizawatee, N. M., N. A. Jamil
}

To Link this Article: http://dx.doi.org/10.6007/IJARBSS/v11-i1/8229

DOI:10.6007/IJARBSS/v11-i1/8229

Received: 19 November 2020, Revised: 10 December 2020, Accepted: 24 December 2020

Published Online: 13 January 2021

In-Text Citation: (Jamaludin et al., 2021)

To Cite this Article: Jamaludin, N. L., Azhar, Salizawatee, N. M., \& Jamil, N. A. (2021). The Influence of Personal Values on Organization Commitment among Foreign Workers in Malaysia's Construction Industry. International Journal of Academic Research in Business and Social Sciences, 11(1), 126-145.

\section{Copyright: (c) 2021 The Author(s)}

Published by Human Resource Management Academic Research Society (www.hrmars.com)

This article is published under the Creative Commons Attribution (CC BY 4.0) license. Anyone may reproduce, distribute, translate and create derivative works of this article (for both commercial and non-commercial purposes), subject to full attribution to the original publication and authors. The full terms of this license may be seen at: http://creativecommons.org/licences/by/4.0/legalcode

Vol. 11, No. 1, 2021, Pg. 126 - 145

Full Terms \& Conditions of access and use can be found at http://hrmars.com/index.php/pages/detail/publication-ethics 


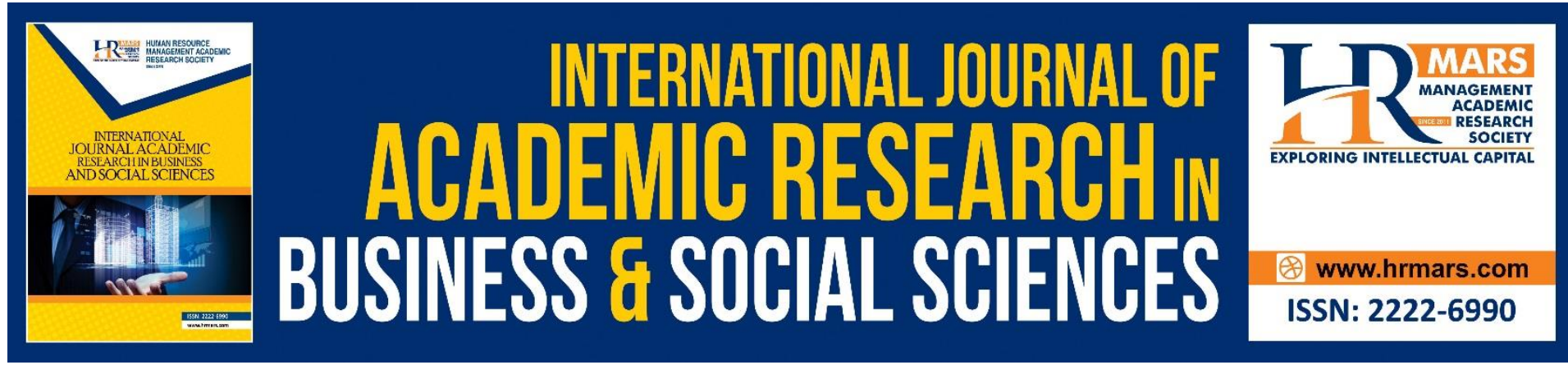

\title{
The Influence of Personal Values on Organization Commitment among Foreign Workers in Malaysia's Construction Industry
}

\author{
N. L. Jamaludin
}

Senior Lecturer at Department of International Business and Management Studies, Faculty of Business and Management, Universiti Teknologi MARA, Puncak Alam, Selangor, Malaysia

Email: norlelawati0019@uitm.edu.my

\begin{abstract}
Azhar
Construction Industry Development Board (CIDB) Malaysia, Shah Alam Selangor

Email: myazrin79@gmail.com
\end{abstract}

Salizawatee, N. M.

Senior Lecturer at Department of International Business and Management Studies, Faculty of Business and Management, Universiti Teknologi MARA, Puncak Alam, Selangor, Malaysia

Email: salizawatee@uitm.edu.my

N. A. Jamil

Senior Lecturer at Department of Operation Management, Faculty of Business and Management, Universiti Teknologi MARA, Puncak Alam, Selangor, Malaysia

Email: norina0048@uitm.edu.my

\begin{abstract}
This study begins from the realisation of the important contributions of employees' Personal Values on Organizational Commitment especially in construction Industry in Malaysia where there is paucity of research in this area. The independent variables are Personal Values (Stimulation, Universalism, Achievement, Self-Direction and Benevolence). The dependent variable is the Organisational Commitment (Affective Commitment, Continuance Commitment and Normative Commitment). The sampling frame ( $\mathrm{N}=160)$ is concentrated on the technical foreign workers who work in Construction Industry Development Board (CIDB). The data was analysed using Statistical Package for the Social Sciences25 (SPSS 25). Results show that Achievement values and Self-Direction values are proven to have important influences on Organizational Commitment. This study discusses the results from the social, psychological, and human resource perspectives, as well as their implications for human resource management.
\end{abstract}


Keywords: Personal Values (Stimulation, Universalism, Achievement, Self-Direction and Benevolence), Organisational Commitment (Affective Commitment, Continuance Commitment and Normative Commitment).

\section{Introduction}

The Malaysian economy is currently heavily dependent on foreign workers, including expatriates, professionals and skilled migrants. Foreign workers are mainly employed in the manufacturing, construction and agricultural sectors (Bank Negara Malaysia, 2011). Thus, the importance of studies work-related attitudes related to employee commitment is not hard to justify, given the fact that organization usually invest huge sum of money and time to engaged in up skilling their foreign workforce to serve the organizations effectively (Bernstein and Vilter, 2018).

In addition, an organization's performance has a significant effect on Organisational Commitment and is highly valuable based on highlighted studies (Nehmeh, 2009; Sungu, Weng, Hu, Kitule, \& Fang, 2020). The reason is because it identifies the goals and values of the organization from greatly committed employee, willing to go over and beyond their necessary job duties and has stronger desire to belong to the organisation (Meyer and Allen, 1991). A research by Ahmed and Rafiq (2015) and Ababneh (2020) revealed that higher Organisational Commitment is positively linked to the high satisfaction among foreign employees. Therefore, the factor leading, especially among foreign employees to Organizational Commitment needs to be studied.

Furthermore, Becker (1960) and Bobowik, Jiménez, and Bilbao (2011) suggested that there is a need for research that would take a look at commitment in terms of values. Also, the growth of interest in Personal Values in increasing in management and organisational behaviour research (Hackett, 2007) and, in particular, commitment research (Cohen, 2007). The relationship between values and commitment has been explored by more research, at least from an empirical point of view (see Clugston, 2000 and Cohen, 2007). In addition, since values are attributed a central role in identifying the relation between individuals and the employment organization, the relevance of studies on values and work-related attitudes is imperative (Arieli, Sagiv, \& Roccas, 2020).

The underlying presumption is that when their interests are aligned with those highlighted in the company, individuals will be happier and more inspired, fulfilled, and devoted (Berings, 2004). Therefore, an awareness of variations in values at the individual level could provide insight into better ways of handling diverse employees (Francesco and Chen, 2004) and help to increase both their commitment, whose results extend to both the spheres of work and life (Cohen and Shamai, 2010).

However, in seeking a structured order for the identification of Personal Values, Schwartz (1992) proposed the Theory of Basic Human Values in which values are classified in terms of the motivational goal they express. The structure of dynamic relations that demonstrates between value-types is one of the main elements in this theory (Sánchez, 2014). Therefore, there are practical, psychological and social implications of behaviour in pursuit of some value that may either contradict or be congruent with the pursuit of other values (Sánchez, 2014). 
According to Sagiv and Schwartz (2000), values that reflect growth needs become more important when an individual reaches the goals to which the values are guided. As stated by Bilsky and Schwartz (1994), in the Personal Value Model, Self-Direction, Universalism, Benevolence, Achievement, and Stimulation are identified as growth needs. Further, a study by Jin and Cui (2013) found that a component of growth need have influence the subjective well-being of employees, which will further influence the commitment amongst foreign employees.

Nevertheless, the outcome of research on correlations between personal values and employee's commitment is inconclusive. Glazer (2004) found that openness to change had a negative relationship with affective commitment. Additionally, Fischer and Smith (2006) found that Conservation and Openness to Change had no direct impact on Affective Organizational Commitment. For this purpose, this study will further examine whether personal values are related to organisational commitment. In addition, the relationship between values and Organizational Commitment has been discovered by individual level research (see Clugston, 2000; Cohen, 2007, 2009, 2010).

CIDB had a total of 200 foreign technical staff in the company in 2018. Nonetheless, out of 200,40 workers chose to detach themselves from an organisation that includes up to $20 \%$ of foreign technical workers. Thus, further studies are warranted to clarify this phenomenon. Studies have shown that employee turnover can result in a high organisational cost (Coetzer et al., 2017). Further, retention of employees who understand the organization, their responsibilities and who adhere to professional standards is valuable to the organization. Therefore, gaining insight regarding individual and organizational characteristics would be a positive contribution to heightening awareness of how values influence employees' commitment in the organizations in which they work. In addition, CIDB recently conducted its internal employee satisfaction study, as it basically tests and understands the devotion of their workers. Results suggest that almost half of the organisational population also prefers to remain with the company for less than 2 years. This study was carried out to further explore factors influencing the commitment of employees in the CIDB to helps retain the employees for organizations sustainability.

In addition, the relationships between foreign worker's values and commitment are worth investigating because these relationships could have an impact on the actions of foreign workers, a topic in which all of society has an interest. We can understand how differences in values impact their commitment only by clarify the value fit, enabling the selection of recruits who make a good fit with the value system formulated and created by the relevant decisionmakers (Cohen and Shamai, 2010). Knowledge gained about values and how they impact commitment and workplace behaviors of foreign worker may provide another tool to help strengthen and promote the occurrence of ethical decision making and behaviors among these employees. Moreover, according to Cohen and Shamai (2009); Katou \& Budhwar (2012); Lee, Chiang, Van Esch, \& Cai, (2018) and Kutaula, Gillani \& Budhwar (2020), study on individual values and commitment occurs mainly in America and Europe. Therefore, it is justified to examine the relationship between these variables in the region where it is plausible, such as Malaysia. 
Based on The Human Theory by Schwartz, Cohen and Shamai (1992, 1996, 2000, 2007 and 2009), Organizational Commitment Theory by Cohen (2010) and other relevant literature, this research argues that the variables analysed can be used as a starting point in the design of studies related to key issues relating to the perceptive of Personal Values of employees to influence Organisational Commitment. The goal of this research was to investigate the correlation between foreign workers' Personal Values (Stimulation, Universalism, Achievement, Self-Direction and Benevolence) and Organisational Commitment (Affective, Continuance and Normative).

The novelty of this study is the contribution of the present body of knowledge through the development of adapted model of Personal Values in relation to Organizational Commitment in construction industry. The development of the adapted model is expected to be implemented in other similar studies to enhance the efficiency of construction industry organisations. Research on the Personal Values and Organisational Commitment of foreign workers in the technical migrant category within an organisation in Malaysia is currently minimal. Therefore, it is justified to investigate the correlation of these variables in the region where it is still plaucibe, such as Malaysia.

The findings of this study are essential to provide on some valuable information to publics and also to the employees. Thus, with the information collected and extensive research studies, it could be planned for the future to have a conclusive finding. Scientific data about the viable relationships among Personal Values can be very precious to the ever-expanding frame of know-how related to Organisational Commitment.

Observations made in the literature on personal values and organizational commitment indicates gaps in the following areas:

1) This research aims to investigate the said relationships of foreign worker in the category of technical migrant in construction industry. Limited research focuses on the studied variables within the Malaysian social and cultural context. As suggested by Cohen (2007) and Sagiv and Schwartz (2000), values should be playing a functioning role in work related with processes. Moreover, even though numerous findings have emerged from studies on commitment in the workplace (Cohen, 2003; Meyer, 2002), the relationship between Individual Values and Commitment within the place of job for foreign workers has typically been overlooked.

2) In addition, according to Cohen and Shamai (2009), research about Individual Values and Commitment mostly occurs in America and Europe. Thus, investigative the relationship of these variables in the area where it is still plausible such as Malaysia is warranted.

3) Finegan's (2000); Schwartz and Bardi's (2001) findings suggested that personal values may influence affective and normative organizational commitment. However, to the researcher knowledge, no study has found the link between personal value and continuance commitment. Meyer and Allen (1997); Khalid (2020); Kumasey, Bawole and Hossain (2017) and Verasamy, Majid and Jamaluddin (2020) argued that one can achieve a better understanding of an employee's relationship with an organization when all three forms of commitment are considered together. Based on this contention, current study subscribe to 
the Three Commitments (Affective, Continuance and Normative) have to be studied together to better understand Organizational Commitment among foreign workers.

This research adds to the literature on this topic and fills the gaps in the recognition that psychological elements need to be further explored by the construction industries to enhance their employees Organisational Commitment. This research provides the industry with a framework about the close relationship between the variables studied. This research was carried out on the basis of the premise that it is imperative to consider the Personal Values of workers to assess whether the company meets its needs in order to strengthen their commitment.

The results provide employers, management and even policy makers with a consistent and holistic view of developing and enhancing employee commitment through an efficient recruiting and selection process. This study therefore contributes to the improvement of the organisation, the learning environment, the growth of talent and the empowerment of quality human capital and can be used as a guide for improvement and implementation in various construction industry organisations in Malaysia and helps in some way to contribute to better performance and enable Malaysia to compete among developed countries or emerging economies.

\section{Literature Review}

According to Meyer and Allen (1997), commitment can be divided in three dimensions. The first dimension is called Affective Commitment, the second dimension is called Continuance Commitment, and the third dimension is called Normative Commitment. Based on Meyer and Allen (1984), Affective Commitment is defined as the basis of as a positive feeling of identification with, attachment to and participation in the work company. Continuance Commitment happens when workers feel dedicated to their communities by using distinctive characteristics of the fees they feel are correlated with quitting. Thirdly, Normative Commitment is the individual's feelings of responsibility based on supposed attachment to the aims of the organisation (Singh and Gupta, 2015).

The correlation between Personal Values and Organizational Commitment is demonstrated in the study by Bardi's (2001) and Finegan's (2000). Values are motivational objectives that impact behaviors, behaviors and judgments (Fischer and Boer 2016). Additionally, human actions, motives, goals, attitudes, activities and assessments are affected by values (Ferssizidis et al., 2010; Fischer \& Boer, 2016; Homer \& Kahle, 1988).

The relationship between Personal Values and Organisational Commitment is seen in the results of Bardi's (2001) and Finegan's (2000) studies. Therefore, in an effort to explain the interpretation of the relationship between Personal Values and Organisational Commitment, theories and principles have been propounded together to better understand the relationship. Some of the theories and concepts are discussed next.

\section{Dependent Variable}

\section{Organisational Commitment}

The powerful motivational implications of commitment can be recognised as organisational commitment (Becker, 1992). Organizational commitment, according to Reilly (1989), is 
typically conceived of as an individual's psychological bond to an organization, including a sense of job involvement, loyalty, and a belief in the values of the organization. Other than that, Porter (1974) claimed that someone is highly committed to organisation when there is a strong understanding of the aims and values of the employer, willingness to exert widespread attempt on behalf of the corporation and strong choice to maintain club inside the corporation.

In addition, Wiener and Vardi (1980) claim that an employee believes he has to stay in the organisation due to their obligation toward employer. The researchers conclude that commitment requires some sort of bonding between individuals and the organisation. Therefore, the concept from Porter (1974) is chosen to serve the scope of research, where he claimed that someone is strongly committed to organisation when there is a deep belief in and recognition of the goals and values of the organisation, willingness to make substantial efforts on behalf of the organisation and a strong desire to retain membership in the organisation. Commitment can be divided into three dimensions, according to Meyer and Allen (1997). The first dimension termed as Affective Commitment, the second dimension called as Continuance Commitment and the third dimension called as Normative Commitment. Meyer and Allen (1997); Kumasey, Bawole and Hossain (2017) and Verasamy, Majid and Jamaluddin (2020) argued that when all three types of commitment are studied together, one can gain a deeper understanding of the relationship of an employee with an organisation. Thus, based on this suggestion, this research was conducted.

The results of Bardi's (2001) and Finegan's (2000) research show this relationship between Personal Values and Organisational Commitment. The pan-cultural values theory of Schwartz and Bardi (2001) explains the reason why vision and values of humanity could inspire commitment. The ideals of vision and humanity usually match the kinds of Benevolence, Universalism and Self-Direction of pan-cultural values. In addition, results from Finegan (2000) are consistent with the theory of values from Schwartz and Bardi (2001) who suggest that a general human preference for Benevolence, Universalism and Self-Direction can translate into changes in behaviors in the workplace.

\section{Independent Variables Personal Values}

Based on Shalom Schwartz (1992; 1994; 2006), this study mostly complies with the assumption of human values when talking about values, which first established ten distinct types of Personal Values, such as Universalism, Benevolence, Tradition, Conformity, Stability, Power, Accomplishment, Hedonism, Stimulation, and Self-Direction at the individual level. Values that reflect growth needs (e.g. Self-Actualization) become more important when an individual reaches the goals to which the values are guided, according to Sagiv and Schwartz (2000). As shown by Bilsky and Schwartz (1994), Self-Direction, Universalism, Benevolence, Accomplishment, and Stimulation are identified as growth needs in the Personal Value model. A study by Jin and Cui (2013) found that a component of growth need to affect the subjective well-being of employees with a further effect on the commitment of employees among foreign workers.

Schwartz (2012) concluded that people with Stimulation-Value orientation are more oriented on excitement, creativity, and challenge. In addition, Schwartz (2012) proposed that people 
with the orientation of Universalism-Value are more conscious, appreciative, supportive and respectful of the welfare of all people and of nature. Other than that, he added that people with Achievement-Value orientation are more likely to pursue personal accomplishment by displaying competence according to a social norm and social acceptance, and more critical thinking, curiosity and self-respect are available to people with Self-Direction Value orientation. Finally, persons with a Benevolence-Value mindset are more protective and aim to boost the well-being of those they are in regular personal contact with.

The findings suggest higher levels of commitment when organisations are viewed as reflecting ideals associated with Benevolence and Vision (Verasamy, Majid and Jamaluddin, 2020). The ideals of vision and humanity usually correlate with the forms of pan-cultural values of Benevolence, Universalism and Self-Direction. In accordance with Maslow (1959), Schwartz and Bardi (2001) argue that international workers are those who fulfill basic human needs, such as Benevolence, Self-Direction and Universal types of values. In addition, the findings of Finegan (2000) are consistent with the theory of values of Schwartz and Bardi (2001) and indicate that a general human preference for Benevolence, Universalism and Self-Direction may translate into changes in behavior in the workplace.

Thus it is possible to further examine the relationship between personal values (SelfDirection, Universalism, Benevolence, Accomplishment, and Stimulation) and Organisational Commitment. Table 1 . describes the importance of the five growth values defined by Schwartz (1992) and referred to in Campos Sánchez (2014).

Table 1: Descriptions of the Five Personal Values

\begin{tabular}{cl}
\hline PersonalValues & \multicolumn{1}{c}{ Definition } \\
\hline Self-Direction & $\begin{array}{l}\text { Concerned with independent thought and action-choosing, } \\
\text { creating, exploring }\end{array}$ \\
\hline Universalism & $\begin{array}{l}\text { Concerned with understanding, appreciation, tolerance, and } \\
\text { protection for the welfare of all people and of nature }\end{array}$ \\
\hline Benevolence & $\begin{array}{l}\text { Concerned with preservation and enhancement of the welfare of } \\
\text { people with whom one is in frequent personal contact }\end{array}$ \\
\hline Achievement & $\begin{array}{l}\text { Concerned with personal success through demonstrating } \\
\text { competence according to social standards }\end{array}$ \\
\hline Stimulation & Concerned with excitement, novelty, and challenge in life \\
\hline
\end{tabular}

\section{Relationship between Personal Value and Organizational Commitment}

In order to fully understand commitment, Becker (1960) suggested the need to explore and test the relationship between commitment and values; we must discover the value systems through which the mechanisms and processes mentioned earlier operate. In addition, Furnham (2005) advanced the theory of why values related to commitment and he said that affective nature has an enveloping effect on how individuals, including their job or organisation, perceive the world. Different individuals have different personalities, and each element in the setting will respond in another way. This contributes to the point that certain persons have a value system based on greater commitment than different human beings. In addition, a research by Ying Hui and Aaron Cihen (2010) and Verasamy, Majid and Jamaluddin 
(2020) shows that individual values have an encouraging effect on the employees' Organisational Commitment.

Meyer and Allen (1997); Kumasey, Bawole and Hossain (2017) and Verasamy, Majid and Jamaluddin (2020) suggest that researchers should review the three proposed dimensions (Affective Commitment, Continuance Commitment and Normative Commitment) altogether to better understand Organisational Commitment. This research seeks to understand how things function and focuses on verifying the hypotheses on the basis of the literature findings mentioned in this chapter. A positivist approach is considered practical to understand how to obtain the necessary information, improve understanding of the relationships between independent and dependent variables and in turn, provide significant results due to the nature of hypothesis testing for this research. As such, this research refines the theory of positivism in order to analyse the empirically complex range of social and organisational variables based on the following hypotheses:

$\mathrm{H} 1$ = Stimulation have a positive and significant relationship with Organizational Commitment

$\mathrm{H} 2$ = Universalism have a positive and significant relationship with Organizational Commitment

$\mathrm{H} 3$ = Achievement have a positive and significant relationship with Organizational Commitment

$\mathrm{H} 4$ = Self-Direction have a positive and significant relationship with Organizational Commitment

$\mathrm{H} 5$ = Benevolence have a positive and significant relationship with Organizational Commitment

\section{Methodology}

\section{Data Collection}

A self-administered questionnaire was made with suitable modifications from previous studies to measure the impact of Personal Values towards Organization Commitment of employees in the CIDB, which is focused on the technical foreign from Jan to Mac 2020.

\section{Sampling Details}

In this study, the population involves foreign employees who work with CIDB Negeri Selangor. The total number of technical migrants in CIDB Negeri Selangor is 160 (100\%) permanent technical foreign workers.

\section{Measurement of the Variables}

\section{Background Information}

The background information collected included gender, age, nationality and years of service.

\section{Independent and Dependent Variables \\ Personal Values Questionnaire (PVQ)}

The PVQ (Schwartz, 2006) was used to assess Personal Values. The PVQ scale includes short verbal portraits of 40 dissimilar people. For each of the portraits, respondents respond the questions "How much like you is this person?" on a six-point scale $(1=$ not like me at all to 6 = very much like me). Sample questions are as follows: "He/she thinks it is important to be ambitious. He or she can strive to do better than others." 


\section{Organizational Commitment Questionnaire (OCQ)}

The OCQ by Allen \& Meyer (1990) are used to predict employee's commitment measures a seven ( 7 ) - point scale ( 1 = strongly disagree to $7=$ strongly agree). This questionnaire is composed, in its full length, of 24 items, eight (8) items in each of the following claimed dimension commitment scale: Affective, Continuance and Normative Commitment. Sample questions are as follows: "I do not feel a strong sense of belonging to my organization; Right now, staying with my job at this organization is a matter of necessity as much as desire."

\section{Statistical Analysis}

The analyses were conducted using IBM SPSS 25.0. In this study, the tests performed were validity and reliability tests as well as four classical assumption tests (normality, autocorrelation, multicollinearity, heteroscedasticity test). Next, correlation analysis was performed to ensure the relationships and the power amongst all of the variables that researcher test. In addition, linear relationship between dependent and independent variables was interpreted using regression analysis to predict how well the independent variables able to explain dependent variables.

\section{Results}

\section{Data Screening}

The related assumptions of the statistical analysis were checked prior to performing the regression analysis. To reflect on the accuracy of the measuring instrument in providing the results for this study, a reliability test was performed. The satisfactory degree of reliability often depends on how a measure is being used, despite the general acceptance of a value of 0.7 as the cut-off point of the reliability measure. Despite the general acceptance on the value of 0.7 as the cut-off point of reliability measure, the satisfactory level of reliability also depends on how a measure is being used. 'In the early stages of research on predictor tests or hypothesized measures of a construct, one saves time and energy by working with instruments that have only modest reliability, for which purpose reliabilities of 0.60 or 0.50 will suffice (Sekaran, 2003). Next the testing of multivariate outliers was performed using Mahalanobis Distance. According to the Chi-square statistics table $P=.001$ and the 5 independent variables are 19.73 (20.52), an analysis of the Mahalanobis distance scores indicated two multivariate outliers. The outliers found in the initial screening of data were removed.

Furthermore, the Komogorov-Smirnov and Shapiro-Wilk and Skewness and Kurtosis test results indicate that the residuals are all normally distributed. Next the Durbin Watson values were 2.470 , suggesting both positive and negative non-autocorrelation occurring between the residuals in the regression models. In addition, the results of the VIF demonstrate that this study does not have a multicollinearity problem. The higher VIF for Benevolence based on outcome is 3.962 and the lower VIF for Achievement is 2.460 .

\section{Reliability and Normality Analysis}

Following suggestions by Nunnally (1978), the internal reliability for this study was verified by Cronbach alpha values of $0.647-0.867$. However the researcher noted that any discussion of interpretation and implications involving the slightly low Cronbach Alpha variable is provisional and demands replication to further validate the associations between variables. In addition, the researcher studied the Skewness and Kurtosis value normality test to 
determine its normality. The results show that the values of Skewness vary from -0.408 to 0.628 and the values of Kurtosis range from 0.214 to 2.821 , suggesting that the variables are in the normal range (Pallant, 2010).

\section{Descriptive Analysis}

Results indicate that $66.2 \%$ were male respondents and $33.8 \%$ were female respondents. It has shown that this research dominated by males. In addition, the majority of workers employed in the construction industry are male. Next, results show that the majority of respondent age ranges from 26 to 30 years (born 1994 to 1998) with (60.6\%) followed by the second larger number with $18.8 \%$, which is 31 to 40 years (born 1980 to 1989). It shows that the greatest number of age ranges employed in the CIDB are people born from 1994 to 1998. In addition, the result is $16.3 \%$ for 20-25 years of age (born from 2000 to 2005) while the lowest respondent age is 40 years of age and above (born from 1944 to 1964) (4.3\%). Finally, for the nationality of CIDB respondents, the results show that Indonesia (80.6\%) is the country with the largest number of skilled migrants in the CIDB, followed by Bangladesh (16.8\%) and Nepal (1.3\%). For years of service, the majority of all foreign technical employees work for 15 years (58.8\%) with 94 people, followed by $6-10$ years (27.5\%) with 44 people. Finally, with 12 people, the third highest length of years of service was $11-15$ years $(7.5 \%)$, while the lowest length was more than 16 years (6.2\%) with 10 people. For detail information on the profiles of the respondents, see Table 2.

Table 2: Profile of Respondents

\begin{tabular}{|c|c|c|c|}
\hline Number & Variables & Frequency & Percent (\%) \\
\hline \multirow{3}{*}{1} & Gender & & \\
\hline & Male & 106 & 66.2 \\
\hline & Female & 54 & 33.8 \\
\hline \multirow{5}{*}{2} & Age & & \\
\hline & $20-25$ years old & 26 & 16.3 \\
\hline & 26 - 30years old & 97 & 60.6 \\
\hline & 31 - 40years old & 30 & 18.8 \\
\hline & $\begin{array}{c}40 \text { years old and } \\
\text { above }\end{array}$ & 7 & 4.3 \\
\hline \multirow{5}{*}{3} & Nationality & & \\
\hline & Indonesia & 129 & 80.6 \\
\hline & Bangladesh & 27 & 16.8 \\
\hline & Nepal & 2 & 1.3 \\
\hline & Others & 2 & 1.3 \\
\hline \multirow{5}{*}{4} & Years of Service & & \\
\hline & 1 - 5 years & 94 & 58.8 \\
\hline & 6 - 10 years & 44 & 27.5 \\
\hline & 11 - 15 years & 12 & 7.5 \\
\hline & 16 years and above & 10 & 6.2 \\
\hline
\end{tabular}




\section{Correlation Analysis}

Table 3: Intercorrelations of the Major Variables

\begin{tabular}{lcccccc}
\hline 1.Benevolence & $\mathbf{1}$ & $\mathbf{2}$ & $\mathbf{3}$ & $\mathbf{4}$ & $\mathbf{5}$ & $\mathbf{6}$ \\
\hline 2. Universalism & 1 & & & & & \\
\hline 3. Self-Direction & $\begin{array}{c}0.798^{*} \\
*\end{array}$ & 1 & & & & \\
\hline 4. Stimulation & $\begin{array}{c}0.716^{*} \\
*\end{array}$ & $\begin{array}{c}0.741^{*} \\
*\end{array}$ & 1 & & & \\
\hline 5. Achievement & $\begin{array}{c}0.763^{*} \\
*\end{array}$ & $\begin{array}{c}0.688^{*} \\
*\end{array}$ & $\begin{array}{c}0.710^{*} \\
*\end{array}$ & 1 & & \\
\hline $\begin{array}{l}0.647^{*} \\
\text { 6.Organizational }\end{array}$ & $\begin{array}{c}0.613^{*} \\
*\end{array}$ & $\begin{array}{c}0.651^{*} \\
*\end{array}$ & $\begin{array}{c}0.687^{*} \\
*\end{array}$ & 1 & \\
Commitment & $0.186^{*}$ & $0.146^{*}$ & $\begin{array}{c}0.266^{*} \\
*\end{array}$ & $\begin{array}{c}0.222^{*} \\
*\end{array}$ & $\begin{array}{c}0.367^{*} \\
*\end{array}$ & 1 \\
\hline
\end{tabular}

**. Correlation is significant at the 0.01 level (1-tailed).

*. Correlation is significant at the 0.05 level (1-tailed).

Based on the results in Table 3, there is medium and small correlation linear relationship between Benevolence, Universalism, Self-Direction and Stimulation towards Organizational Commitment.

\section{Regression Analysis and Hyphotheses Testing}

The model's $R^{2}$ value is 0.159 and the adjusted $R^{2}$ is 0.130 , based on the dependent variable for Organizational Commitment result in Table 4. Therefore, it can be concluded that $13 \%$ of the variance in explaining organisational commitment is explained by the model consisted of Personal Values. For the model, the $f$ value is $5.510(p<0.05)$, implying that the model is significant and that the dependent variables are significantly explained by all independent variables. Two (2) was found to have a significant contribution to Organizational Commitment, which is $(H 3)$ Achievement $(\beta=0.365, p<0.05)$ and $(H 4)$ Self-Direction $(\beta=$ $0.300, p<0.05)$, from all five (5) independent variables. No significant contribution was found to Organisational Commitment between (H5) Benevolence $(\beta=-0.042, p>0.05),(H 2)$ Universalism $(\beta=-0.196, p>0.05)$ and $(H 1)$ Stimulation $(\beta=-0.109, p>0.05)$. Therefore, only two (2) personal values which were Achievement and Self-Direction supported Organisational Commitment. In order to increase Organisational Commitment among foreign workers, these two personal values can be used as a tool for the CIDB. 
Table 4: Results of Organizational Commitment

\begin{tabular}{|c|c|c|c|}
\hline \multirow[b]{2}{*}{ Hypotheses } & \multicolumn{3}{|c|}{ Standard Coefficients (Beta) } \\
\hline & $\beta$ & Sig & Results \\
\hline $\begin{array}{l}\mathrm{H} 1=\text { Stimulation have a positive and } \\
\text { significant relationship with Organizational } \\
\text { Commitment }\end{array}$ & -0.109 & 0.423 & $\begin{array}{c}\text { Not } \\
\text { Supported }\end{array}$ \\
\hline $\begin{array}{l}\mathrm{H} 2=\text { Universalism have a positive and } \\
\text { significant relationship with Organizational } \\
\text { Commitment }\end{array}$ & -0.196 & 0.187 & $\begin{array}{c}\text { Not } \\
\text { Supported }\end{array}$ \\
\hline $\begin{array}{l}\text { H3 = Achievement have a positive and } \\
\text { significant relationship with Organizational } \\
\text { Commitment }\end{array}$ & 0.365 & 0.003 & Supported \\
\hline $\begin{array}{l}\mathrm{H} 4 \text { = Self-Direction have a positive and } \\
\text { significant relationship with Organizational } \\
\text { Commitment }\end{array}$ & 0.300 & 0.044 & Supported \\
\hline $\begin{array}{l}\text { H5 = Benevolence have a positive and } \\
\text { significant relationship with Organizational } \\
\text { Commitment }\end{array}$ & -0.042 & 0.781 & $\begin{array}{c}\text { Not } \\
\text { Supported }\end{array}$ \\
\hline F value & & 5.510 & \\
\hline $\mathrm{R}^{2}$ & & 0.159 & \\
\hline Adjusted $\mathrm{R}^{2}$ & & 0.130 & \\
\hline
\end{tabular}

\section{Discussion}

The primary objective of this research was to obtain a deeper understanding of the relationship between psychological factors and commitment of foreign workers. By briefly describing the interplay between variables that cause Organisational Commitment, this study begins to outline the model.

The first research objective (1) explored the correlation between Personal Value (Stimulation, Universalism, Achievement, Self-Direction and Benevolence) and Organisational Commitment (Affective, Continuance and Normative) among international employees. This study uncovered the organization's relationship between Personal Values and Organisational Commitment. Achievement and Self-Direction were shown to have significant influences on foreign workers' Organisational Commitment. Furthermore, the second research objective (2) explores which Personal Values is more important in influencing Organizational Commitment among foreign workers. This study found that Achievement is the most significant values followed by Self-Direction to influence Organisational Commitment among foreign employees.

This research is perhaps one of the few attempts to apply the theory of Schwartz $(1992,1999)$ to the established theory and measurement of Organisational Commitment and its findings were quite encouraging with regard to the application of Schwartz's Theory to a better understanding of work attitudes such as commitment. The reference point for this research was that Personal Values and Organisational Commitment could be significant to an organization's human resources policy. Nevertheless this argument turned out not to be as 
simple as the researchers thought. Three out of five of the relationships between Personal Values and Commitment to organisation turned out not to be significant.

The result of Stimulation Value Orientations-Organizational Commitment demonstrates that Stimulation is not correlated to the Organizational Commitment $(\mathrm{H} 1)$ of foreign employees. It seems the requirements of being adventurous, exciting and independent may not be significant predictors of their commitment in the construction industry, and for foreign workers in Malaysia in particular.

The researchers found that Achievement and Organizational Commitment have a significant and positive relationship. $13 \%$ in Organizational Commitment $(\mathrm{H} 3)$ was explained by the model. The notion that Achievement-Focused Values (Achievement) foster Organisational Commitment among employees (Arieli, Sagiv, \& Roccas, 2020) also supports this finding.

Similarly significant relationships between Self-Direction and Organisational Commitment (H4) was also shown in the result. An emphasis on independent thoughts and behavior (Schwartz 2012) contributes to Self-Direction. The significant relationship can reflect the fact that autonomy for foreign workers is an important source of commitment.

The belief that Social-Focused Values (Universalism) ( $\mathrm{H} 2)$ and (Benevolence) $(\mathrm{H} 5)$ promote Organisational Commitment (Arieli, Sagiv, \& Roccas, 2020) did not support this finding. In other words, for those with whom one is in regular personal contact (the in-group), foreign workers do not seem to prefer conditions that foster selflessness, understanding, respect, tolerance and security.

Although this study found only minimal support for the relationship between Personal Values and Organisational Commitment, the researcher argues that dismissing the possible relationship as non-existent might be premature. Before firm conclusions can be drawn, further research on these relationships can be needed. Nevertheless, it can be suggested on the basis of the findings that stakeholders in the construction industry focus more on Achievement as a Personal Value that strengthens Organisational Commitment to foreign workers while enforcing recruitment, regulations and policy practices for human resources.

Finally, practical contributions are also made through the study. Commitment is regarded as a precious attitude. Knowing the patterns of individual values that enhance workplace commitment could give top management more insights into the personal roots of commitment and increase their tolerance of individual variations in this sector. This information can be used through socialization, training, or selection processes to increase the commitment of individuals. In order to examine more thoroughly the effect of values on commitment, more research is naturally needed. Research into factors that mediate and moderate the relationship between Personal Values and Commitment can make a particularly significant contribution to this relationship's understanding.

In addition, organisation practitioners can further nurture the significant relationship between Achievement, Self-Direction and Organisational Commitment by adjusting the recruitment, introduction and training programs and providing support throughout the duration of the foreign worker sojourn. In view of this along with the results of the current 
study, it seems that interventions aimed at improving Personal Values can influence the Organisational Commitment of foreign workers, and this may have economic benefits in the long run. The researcher advises organisations to develop strategies for meaningful interactions that incorporate the organization's foreign workers and make them feel like insiders. Industry professionals should in particular, try to develop a distinctive service that resonates with their core employees.

\section{Limitations of the Study}

The study recognizes the limitations of the approach taken to analyse the overall Organization Commitment process here. Perhaps this discrepancy between the findings is related to foreign workers who follow different values in relation to Organisational Commitment that are not tested in this study.

In general, the findings indicate that some of the relationships between Personal Values and Organisational Commitment depend on the context, thus supporting the argument that the relationships between Personal Values and Organisational Commitment are defined by the specific environment (Sagiv and Schwartz 2000; Arieli, Sagiv, \& Roccas, 2020). The researcher believes the aspect of Personal Values needs to be more examined in relation to Organizational Commitment.

The researcher also acknowledges that the collection of data, which was limited to the CIDB's only group of foreign (technical workers), may suffer from a single-source bias and the generalization of findings to other organisations may be taken with caution owing to their distinct nature of work and national cultures. Samples such as foreign workers from culturally similar and dissimilar countries can also be included in further studies, or perhaps focus specifically on less developed countries that have not recently undergone rapid social changes to determine the validity of the current findings. In addition, the questionnaire was distributed based on the small sample size of the CIDB's foreign staff. In order to obtain more effective results, future researchers are advised to increase the sample size.

\section{Recommendations for Organization}

Study findings have significant implications for policy makers and organisations in the design of workshops, assessments, and interventions that contribute to the impact of positive Organisational Commitment. The results show that industry players need to strategically adapt to the various value preferences, specifically looking at the role of Achievement and Self-Direction among foreign workers. By adjusting the introduction or recruitment process, this can be done. Somehow by improving the orientation and arrival services, they can do this. This will further integrate foreign workers' in the organization and make them feel like insiders.

\section{Recommendations for Future Research}

For further work to be suggested by the researcher, predictors of Organisational Commitment are required. Further examination can be carried out by expanding the proposed model to include other constructs in the relationship between Personal Values and Organisational Commitment, i.e., predictors such as personality (Van Oudenhoven and Van der Zee, 2002) and stress resilience (Grant and Kinman, 2012). In addition, the researcher would like to recommend future researchers to look at moderating or mediating variables from this 
research that would affect Organisational Commitment. Job involvement and subjective wellbeing could be the moderator variables which can be tested to indicate the presence of Organisational Commitment in the organisation.

Future research should also take into account that individuals sometimes behave or express ideas about social concerns that are at variance with their personal values (Campos Sánchez, 2014). In this sense, the analysis of the inconsistencies between the Personal Values of foreign workers and their behavior should be the focus of a future line of research. This is because contextual factors may sometimes override personal values (Boer \& Fischer, 2013).

\section{Conclusion}

This study offers some insights into the psychological aspects of foreign employees in a foreign country. The experiences of these employees undoubtedly influence how they perceive Organisational Commitment. In short, the research art of this study draws attention to the complexity of the process of development of human resources together with the primary objective of understanding the Organisational Commitment of foreign workers. It can be concluded that concentrating on values of Achievement and Self-Direction could also prove to be a good strategy. The researcher argues that the current study provides some insights into the potential of Personal Values for foreign employees to influence Organisational Commitment. This study however has addressed the gaps in the Personal Values-Organizational Commitment study and contributes significantly to the literature on this subject. Results have confirmed that to remain competitive, industries need a psychological element. In conclusion, the study presents answers to a range of perspectives. At the same time, many questions regarding the Personal Values-Organizational Commitment investigation have been raised.

\section{References}

Ababneh, K. I. (2020). Effects of met expectations, trust, job satisfaction, and commitment on faculty turnover intentions in the United Arab Emirates (UAE). The International Journal of Human Resource Management, 31(2), 303-334.

Al-Jabari, B., \& Ghazzawi, I. (2019). Organizational Commitment: A Review of the Conceptual and Empirical Literature and a Research Agenda. International Leadership Journal, 11(1).

Allen, N. J., and Meyer, J. P. (1990). The measurement and antecedents of affective, continuance and normative commitment to the organization. Journal of Occupational Psychology, 63, 1-18.

Ang, S., Van Dyne, L., and Begley, T. M. (2003). The employment relationships of foreign workers versus local employees: A field study of organizational justice, job satisfaction, performance, and OCB. Journal of Organizational Behavior, 24, 561-583.

Arieli, S., Sagiv, L., \& Roccas, S. (2020). Values at work: The impact of personal values in organisations. Applied Psychology, 69(2), 230-275.

Becker, H. S. (1960). Notes on the concept of commitment. American Journal of Sociology, Vol. 66, pp. 32-40.

Berings, D., De Fruyt, F., and Bouwen, R. (2004). Work values and personality traits as predictors of enterprising and social vocational interests. Personality and Individual Differences, 36, 349-364. 
Bernstein, H., and Vilter, C. (2018). Upskilling the Immigrant Workforce to Meet Employer Demand for Skilled Workers. Urban Institute.

Bilsky, W., Schwartz, S. H. (1994). Values and personality. European Journal Personality, 8(3):163-181.

Bobowik, M., Basabe, N., Paez, D., Jimenez, A., Bilbao, M. A. (2011). Personal values and wellbeing among Europeans, Spanish natives and immigrants to Spain: does the culture matter? Journal Happiness Study, 12(3):401-419.

Cohen, A. (2003). Multiple commitments in the workplace: An integrative approach. Mahwah, NJ: Lawrence Erlbaum Associates.

Cohen, A. (2007). Commitment before and after: An evaluation and reconceptualization of organizational commitment. Human Resource Management Review, 17, 336-354.

Cohen, A. (2007b). An examination of the relationship between commitments and culture among five cultural groups of Israeli teachers. Journal of Cross-Cultural Psychology, Vol. 38, pp. 34-49.

Cohen, A., and Shamai, O. (2009). The relationship between individual values, psychological well-being, and organisational commitment among Israeli police officers. An International Journal of Police Strategies and Management, 33, 30-51.

Clugston, M., Howell, J. P., and Dorfman, P. W. (2000). Does cultural socialization predict multiple bases and foci of commitment? Journal of Management, 26, 5-30.

Cooper-Hakim, A., and Viswesvaran, C. (2005). The construct of work commitment: Testing an integrative framework. Psychological Bulletin, 131, 241-259.

Dose, J. J. (1997). Work values: An integrative framework and illustrative application to organizational socialization. Journal of Occupational and Organizational Psychology, 70: 219-240.

Diener, E., Sandvik, E., and Pavot, W. (1991). Happiness is the frequency, not the intensity, of positive versus negative effect, in Strack, F., Argyle, M. and Schwartz, N. (Eds), Subjective Well-being: An Interdisciplinary Perspective, Pergamon, Oxford, pp. 119-39.

Diener, E., Oishi, S., Lucas, R. E. (2003). Personality, culture, and subjective wellbeing: emotional and cognitive evaluations of life. Annual Review Psychology 54(1):403-425.

Ekhsan, M. (2019). The Influence Job Satisfaction and Organizational Commitment on Employee Turnover Intention. Journal of Business, Management, and Accounting, 1(1), 48-55.

Enz, C. (1989). The relationship between organizational value sharing and influence over strategic decisions. International Journal of Value-Based Management, 2(1), 79-91.

Faul, F., Erdfelder, E., Buchner, A., and Lang, A. G. (2009). Statistical power analyses using G* Power 3.1: Tests for correlation and regression analyses. Behavior research methods, 41(4), 1149-1160.

Farh, J. L., Hackett, R. D., and Liang, J. (2007). Individual-level cultural values as moderators of perceived organizational support-employee outcomes relationships in China: Comparing the effects of power distance and traditionality. Academy of Management Journal, 50, 715-729.

Furnham, A., Petrides, K. V., Tsaosis, I., Pappas, K., and Garrod, D. (2005). A cross-cultural investigation into the relationships between personality traits and work values. The Journal of Psychology, Vol. 139, pp. 5-32.

Finegan, J. E. (2000). The impact of person and organizational values on organizational commitment. Journal of Occupational and Organizational Psychology, 73: 149-169. 
Fischer, R., Boer, D. (2016). Values: the dynamic nexus between biology, ecology and culture. Current Opinion Psychology 8:155-160.

Gelade, G. A., Dobson, P., and Gilbert, P. (2006). National differences in organization commitment: Effect of economy, product of personality, or consequence of culture? Journal of Cross-Cultural Psychology, 37, 542-546.

Glazer, S., Daniel, S. K., and Short, K. M. (2004). A study of the relationship between organizational commitment and human values in four countries. Human Relations, 57, 323-345.

Graham, C., Markowitz, J. (2011). Aspirations and happiness of potential Latin American immigrants. Journal Social Responsibility Policy 2(2):9-25.

Haslam, N., Whelan, J., and Bastian, B. (2009). Big five traits mediate associations between values and subjective well-being. Personality and Individual Differences, 46, 40-42.

Khalid, N. (2020). Artificial intelligence learning and entrepreneurial performance among university students: evidence from malaysian higher educational institutions. Journal of Intelligent \& Fuzzy Systems, (Preprint), 1-19.

Kutaula, S., Gillani, A., \& Budhwar, P. S. (2020). An analysis of employment relationships in Asia using psychological contract theory: A review and research agenda. Human Resource Management Review, 30(4), 100707.

Katou, A. A., Budhwar, P. S. (2012). The link between HR practices, psychological contract fulfillment, and organizational performance: The case of the Greek service sector. Thunderbird International Business Review, 54 (6), pp. 793-809

Ko, J. W., Price, J. L., and Mueller, C. W. (1997). Assessment of Meyer and Allen's threecomponent model of organizational commitment in South Korea. Journal of Applied Psychology, Vol. 82, pp. 961-73.

Kirkman, B. L., and Shapiro, D. L. (2001). The impact of cultural values on job satisfaction and organizational commitment in self-managing work teams: the mediating role of employee resistance. Academy of Management Journal, Vol. 44, pp. 557-69.

Kraaykamp, G., Cemalcilar, Z., \& Tosun, J. (2019). Transmission of work attitudes and values: Comparisons, consequences, and implications. The Annals of the American Academy of Political and Social Science, 682(1), 8-24.

Kumasey, A. S., Bawole, J. N., and Hossain, F. (2017). Organizational commitment of public service employees in Ghana: do codes of ethics matter? International Review of Administrative Sciences, 83(1_suppl), 59-77.

Leiter, M. P., \& Maslach, C. (1988). The impact of interpersonal environment on burnout and organizational commitment. Journal of Organizational Behavior, 9(4), 297-308. doi:10.1002/(ISSN)1099-1379.

Lim, L. (2001). Work cultural values of Malays and Chinese Malaysians. International Journal of Cross Cultural Management, 1(2), 209-226.

Mathieu, J. E., and Zajac, D. M. (1990). A review and meta-analysis of the antecedents, correlates, and consequences of organizational commitment. Psychological Bulletin, 108, 171-194.

Malaysian Employers Federation. (2004). The MEF salary and fringe benefits survey for executives 2003. Kuala Lumpur, Malaysia: Malaysian Employers Federation.

Malaysian Employers Federation. (2005). The MEF salary and fringe benefits survey for executives 2004. Kuala Lumpur, Malaysia: Malaysian Employers Federation.

Malaysia Eleventh Malaysia Plan 2016-2020. (2015). Kuala Lumpur: Percetakan Nasional Malaysia Berhad. 
McCormick, L., \& Donohue, R. (2019). Antecedents of affective and normative commitment of organisational volunteers. The International Journal of Human Resource Management, 30(18), 2581-2604.

Meyer, J. P., and Allen, N. J. (1991). A three-component conceptualization of organizational commitment. Human resource management review, 1(1), 61-89.

Meyer, J. P., \& Herscovitch, L. (2001). Commitment in the workplace: Toward a general model. Human Resource Management Review, 11, 299-326. doi:10.1016/S10534822(00)00053-X.

Meyer, J. P., Stanley, D. J., Herscovitch, L., and Topolnytsky, L. (2002). Affective, continuance and normative commitment to the organization: A meta-analysis of antecedents, correlates, and consequences. Journal of Vocational Behavior, 61, 20-52.

Meyer, J. P., and Maltin, E. R. (2010). Employee commitment and well-being: A critical review, theoretical framework and research agenda. Journal of Vocational Behavior, 77, 323337.

Mowday, R., Porter, L. W., and Steer, R. M. (1982). Employee- organization linkages: The psychology of commitment, absenteeism, and turnover. San Diego, CA: Academic Press.

Nehmeh, R. (2009). What is organizational commitment, why should managers want it in their workforce and is there any cost effective way to secure it. Swiss management center, $5,45-46$.

Nemoto, T., and Beglar, D. (2014). Likert-scale questionnaires. In JALT 2013 Conference Proceedings. (pp. 1-8).

Ogunyemi, A. O., \& Babalola, S. O. (2019). Personal-organisational value congruence in relation to organizational citizenship behaviour and work engagement among the academic staff in South-West Nigerian Universities. Annual Journal of Tecgnical University of Varna, Bulgaria, 3(2), 1-9.

Pearson, C. A. L., and Chong, J. (1997). Contributions of job content and social information on organizational commitment and job satisfaction: an exploration in a Malaysian nursing context. Journal of Occupational and Organizational Psychology, Vol. 70, pp. 357-74.

Porter, L. W., and Steers, R. M. (1973). Organisational, work, and personal factors in employee turnover and absenteeism. Psychological Bulletin, 80(2), 151-176.

Porters, L. W., Steers, R. M., Mowday, R. T., and Boulin, P. V. (1974). Organizational Commitment, Job Satisfaction, and Turnover among Psychiatric Technicians. Journal of Applied Psychology, 59, 603-609.

Tett, R. P., and Meyer, J. P. (1993). Job satisfaction, organizational commitment, turnover intention, and turnover: Path analyses based on meta-analytic findings. Personnel Psychology, 46, 259-293.

Sagiv, L., and Schwartz, S. H. (2000). Value priority and subjective well-being: direct relations and congruity effects. European Journal of Social Psychology, Vol. 30, pp. 177-98.

Schwartz, S. H., Bilsky, W. (1990). Toward a theory of the universal content and structure of values: extensions and cross-cultural replications. Journal Personality and Social Psychology 58 (5):878-891

Schwartz, S. H. (1992). Universals in the content and structure of values: theory and empirical tests in 20 countries, in Zanna, M. (Ed.). Advances in Experimental Social Psychology, Vol. 25, Academic Press, New York, NY, pp. 1-65.

Schwartz, S. H. (1994). Are there universal aspects in the content and structure of values? Journal of Social Issues, 50, 19-45. 
Schwartz, S. H. (1996). Value priorities and behavior: applying a theory of integrated value systems, in Seligman, C., Olsen, J.M. and Zanna, M.P. (Eds). Values: The Ontario Symposium, Vol. 8, Lawrence Erlbaum Associates, Hillsdale, NJ, pp. 1-25.

Schwartz, S. H., Bardi, A. (2001). Value hierarchies across cultures taking a similarities perspective. Journal Cross Culture Psychology 32 (3):268-290.

Schwartz, S. H., Melech, G., Lehmann, A., Burgess, S., Harris, M., Owens, V. (2001). Extending the cross-cultural validity of the theory of basic human values with a different method of measurement. Journal Cross Culture Psychology 32 (5):519-542.

Schwartz, S. H. (2012). An overview of the Schwartz theory of basic values. Online Readings in Psychology and Culture 2(1):11.

Shmotkin, D. (1998). Declarative and differential aspects of subjective well-being and its implications for mental health in later life. In J. Lomranz (Ed.), Handbook of aging and mental health: An integrative approach (pp.15-43). New York: Plenum Press.

Solinger, O., Van Olffen, W. and Roe, R. (2008). Beyond the three-component model of organizational commitment. Journal of Applied Psychology, Vol. 93, pp. 70-83.

Sortheix, F .M., Lönnqvist, J. E. (2014). Personal value priorities and life satisfaction in Europe the moderating role of socioeconomic development. Journal Cross Culture Psychology 45 (2):282-299.

Sortheix, F. M., Lönnqvist, J. E. (2015). Person-group value congruence and subjective wellbeing in students from Argentina, Bulgaria and Finland: the role of interpersonal relationships. Journal Community Applied Social Psychology 25(1):34-48.

Sungu, L. J., Weng, Q., Hu, E., Kitule, J. A., \& Fang, Q. (2020). How Does Organizational Commitment Relate to Job Performance? A Conservation of Resource Perspective. Human Performance, 33(1), 52-69.

Verasamy, P., Majid, A. H. A., and Jamaluddin, N. A. (2020). Generational Diversity, Personal Attributes and Organizational Commitment among Employees of Corporate Consultancies. Jurnal Manajemen and Kewirausahaan, 22(1), 65-72.

Wasti, S. A. (2003). The influence of cultural values on antecedents of organizational commitment: an individual-level analysis. Applied Psychology: An International Review, Vol. 52, pp. 533-54.

Wasti, S. A., \& Can, O. (2008). Affective and normative commitment to organization, supervisor, and coworkers: Do collectivist values matter? Journal of Vocational Behavior, 73(3), 404-413. doi:10.1016/j.jvb.2008.08.003.

Wiener, Y. and Vardi, Y. (1980). Relationships between job, organization and career commitments and work outcomes: An integrative approach. Organizational Behavior and Human Performance, 26, 81-96.

Wright, P. M., and McMahan, G. C. (2011). Exploring human capital: putting 'human'back into strategic human resource management. Human resource management journal, 21(2), 93-104.

Yao, T., Qiu, Q., \& Wei, Y. (2019). Retaining hotel employees as internal customers: Effect of organizational commitment on attitudinal and behavioral loyalty of employees. International Journal of Hospitality Management, 76, 1-8.

Yap, B. W., \& Sim, C. H. (2011). Comparisons of various types of normality tests. Journal of Statistical Computation and Simulation, 81(12), 2141-2155. 